\title{
Primary ovarian angiosarcoma: a rare and recognizable ovarian tumor
}

\author{
Hong Ye, Min Lin, Ruotong Li, Shuming Qin, Gang Hou, Hongzhi Chen and Xiaomei Li
}

\begin{abstract}
The diagnosis of primary angiosarcoma of ovary is still a challenge as it has no specific clinical symptoms and is easily confused with other malignant neoplasms in morphology. Here, we described a case of primary ovarian angiosarcoma and reviewed the literature. A 47-year-old female showed a left ovary mass. Grossly, the cut surface of the tumor was solid and gray-white with intermediate texture. Some areas were spongy and atropurpureus with a soft texture. Microscopically, the tumor cells were arranged into a variety of different structures with visible hemorrhage. Immunochemically, the tumor cells were positive for CD31, ERG, Fli1, D2-40 and vimentin in a strong and diffused manner. CD34 stain showed focal positivity. Epithelial markers (e.g. CK, CK7, CK8/18 and PAX8) were all negative. Negative immunostaining for SMA, S-100, P53 and calretinin also were detected. The proliferative index (Ki-67) was approximately $40 \%$. After surgery, the patient was treated with radiotherapy, targeted therapy and immunotherapy. In the 9-month follow-up, the patient was survival without evidence of disease. The diagnosis of ovarian angiosarcoma required the careful observation of morphology and the reasonable application of immunohistochemistry. Targeted therapy and immunotherapy are the potential directions for the treatment of angiosarcoma.
\end{abstract}

Keywords: Angiosarcoma, Ovary, Pathology, Immunochemistry, Therapy

\section{Introduction}

Angiosarcoma, a rare soft tissue malignancy accounting for $1-2 \%$ of all soft tissue sarcomas, occurs in the skin tissues and soft tissues [1]. It is an infiltrative tumor with high rate of local recurrence and metastasis [2]. Such disease has been reported in liver, spleen, adrenal, heart, gastrointestinal tract and female genital tract (FGT) [3-8]. To our best knowledge, ovarian angiosarcoma is rare, responsible for about $1 \%$ of the ovarian malignancy [9-11]. Most of primary ovarian angiosarcomas are single onset, while partial cases present simultaneous teratoma or ovarian epithelial neoplasms [12].

The diagnosis of primary ovarian angiosarcoma is still a challenge as there are no specific clinical symptoms for these patients. Meanwhile, it is easily confused with

\footnotetext{
*Correspondence: Ixmcjcny@126.com

Department of Pathology, Tai'an Central Hospital, No. 29, Longtan Road, Tai'an 271000, China
}

(c) The Author(s). 2021 Open Access This article is licensed under a Creative Commons Attribution 4.0 International License, which permits use, sharing, adaptation, distribution and reproduction in any medium or format, as long as you give appropriate credit to the original author(s) and the source, provide a link to the Creative Commons licence, and indicate if changes were made. The images or other third party material in this article are included in the article's Creative Commons licence, unless indicated otherwise in a credit line to the material. If material is not included in the article's Creative Commons licence and your intended use is not permitted by statutory regulation or exceeds the permitted use, you will need to obtain permission directly from the copyright holder. To view a copy of this licence, visit http://creativecommons.org/licenses/by/4.0/ The Creative Commons Public Domain Dedication waiver (http://creativecommons.org/publicdomain/zero/1.0/) applies to the data made available in this article, unless otherwise stated in a credit line to the data.

\section{Material and methods}

The specimens were fixed in $10 \%$ buffered formalin after oophorosalpingectomy, followed by embedding in paraffin. The sections $(4 \mu \mathrm{m})$ were stained using hematoxylin and eosin. The histological features were evaluated by two experienced pathologists. Immunohistochemistry stain was conducted with Ventana BenchMark XT automated IHC stainer (Roche, Basel, Switzerland). Sections treated with PBS served as negative control. The positive

other malignant neoplasms in morphology. In clinical settings, there is usually misdiagnosis of primary ovarian angiosarcomas due to high malignant degree, diverse manifestations and rapid progress, which results primary ovarian angiosarcoma. Besides, a literature review was conducted to discuss its clinical features and pathological characteristics. 
control was set using the specific tissues according to the manufacture's instructions. Antibody information was given in Table 1 . The patient signed the informed consent. The study protocols were approved by the Ethical Committee of Tai'an Central Hospital.

\section{Results}

\section{Clinical history}

A 47-year-old female (G2P2) presented to our department with a pelvic mass after physical examination about 10 days ago. The results of serological ovarian cancer markers were as follows: CA125, $9.456 \mathrm{U} / \mathrm{ml}$ (normal range: <35 U/ml); CA19-9, 8.16 U/ml (normal range: < $39 \mathrm{U} / \mathrm{ml}$ ); CA72-4, $2.666 \mathrm{U} / \mathrm{ml}$ (normal range: $<6.9 \mathrm{U} / \mathrm{ml}$ ); CA15-3, $8.836 \mathrm{U} / \mathrm{ml}$ (normal range: $<25 \mathrm{U} /$ $\mathrm{ml}$ ); and CEA, $2.6 \mathrm{ng} / \mathrm{ml}$ (normal range: $<5.1 \mathrm{ng} / \mathrm{ml}$ ). Color Doppler ultrasonography showed a mass $(9 \mathrm{~cm} \times$ $6.3 \mathrm{~cm}$ ) with mixed echo and abundant blood flow signals of a low resistance index (RI) of 0.28 in left adnexa. CT scan revealed a mass shadow $(7.9 \mathrm{~cm} \times 6.2 \mathrm{~cm})$ with irregular soft tissue density in the left appendix area. The mass was nodular and lobulated with clear edges. The uneven lesion was significantly enhanced after contrast enhanced scan (Fig. 1a). During the operation, the left ovary was occupied by a cystic-solid mass presenting multi-chamber and brown fluid. The mass was closely adhered to the surrounding peritoneum and rectum. No ascites was observed. There were no obvious abnormalities in the appearance of the right appendix, uterine and rectal lacunae, greater omentum and pelvic abdominal lymph nodes. The patient received total hysterectomy and bilateral salpingo-oophorectomy with pelvic and abdominal lymphadenectomy, omentectomy, and

Table 1 Antibody information

\begin{tabular}{llll}
\hline Antibody & Clon & Source & Dilution \\
\hline CK & AE1/AE3 & Dako & $1: 100$ \\
CK7 & E29 & Dako & $1: 500$ \\
CK8/18 & Cam5.2 & Dako & $1: 200$ \\
Vimentin & V9 & Dako & $1: 200$ \\
P53 & DO-7 & Dako & $1: 200$ \\
Calretinin & polyclone & Abcam & $1: 500$ \\
CD34 & QBEnd/10 & Dako & $1: 50$ \\
CD31 & JC/70A & Dako & $1: 50$ \\
D2-40 & D2-40 & Abcam & $1: 200$ \\
ERG & ER111 & Dako & $1: 50$ \\
Fli1 & EPR4646 & Abcam & $1: 200$ \\
PAX8 & polyclone & Proteintech Group & $1: 800$ \\
S100 & polyclone & Dako & $1: 2000$ \\
SMA & 1A4 & Dako & $1: 200$ \\
Ki67 & MIB-1 & Dako & $1: 50$ \\
\hline
\end{tabular}

appendectomy. FIGO stage of the patient was IA. After surgery, the patient received 15 fractions of radiotherapy, 2 cycles of targeted chemotherapy using Olaparib (150 mg, b.i.d.), as well as immunotherapy. In the 9-month follow-up, the patient was survival with no evidence of recurrence.

\section{Pathological findings}

Grossly, the left ovary showed enlargement $(5.5 \mathrm{~cm} \times 4.5$ $\mathrm{cm} \times 4 \mathrm{~cm}$ ) with nodular appearance and a gray-white to atropurpureus surface (Fig. 1b). The cutting surface in some regions was solid in a color of gray-white with intermediate texture. In other regions, it was spongy and atropurpureus with soft texture (Fig. 1c).

Microscopically, the tumor was located in the ovarian parenchyma and was poorly circumscribed with infiltrative growth pattern towards the stroma. The tumor cells were arranged into a variety of different structures with visible hemorrhage, including well-differentiated hemangiomatous areas, moderately differentiated fissure and communicating cystic tubular areas, and poorly differentiated solid patchy areas. In well-differentiated areas, there were many vascular lumens of various sizes with partial dilatation, which were filled with blood (Fig. 2a). The lumens were lined with flattened or obese mildly atypical endothelial cells (Fig. 2b). In some areas, tumor cells were lined in an irregular labyrinth cavity structure, with the expansion and anastomosis in the lumen. They were covered with one or more layers of swollen endothelial cells, with papillary and boot-nail protruding into the lumen (Fig. 2c and d). In the poorly differentiated areas, there were solid nests formed by fusiform and epithelioid tumor cells with no obvious channel. Partial tumor cells showed significant pleomorphism with vacuolated nuclei and obvious nucleoli scattered in patch. Mitotic cells (5-10 cells per 10 high power field) were seen including cells underwent atypical mitosis (Fig. 2e). Vacuoles cells that similar to adipoblast cells were observed in focal parts (Fig. 2f).

Immunochemically, the tumor cells were positive for CD31 (Fig. 3a), ERG (Fig. 3b), Fli1, D2-40 (Fig. 3c) and vimentin in a diffused manner. CD34 stain showed focal positivity (Fig. 3d). Besides, the epithelial markers including CK, CK7, CK8/18 and PAX8 were all negative. The immunostaining for SMA, S-100, P53 and calretinin also were negative. The proliferative index (Ki-67) was approximately $40 \%$.

\section{Discussion}

Angiosarcoma, commonly occurs in soft tissues, rarely presents in the FGT, especially in ovary. The incidence of primary ovarian angiosarcoma is $1 / 1,000,000$ of ovarian malignant tumors and it may occur either as pure sarcoma or in combination with other ovarian tumors 

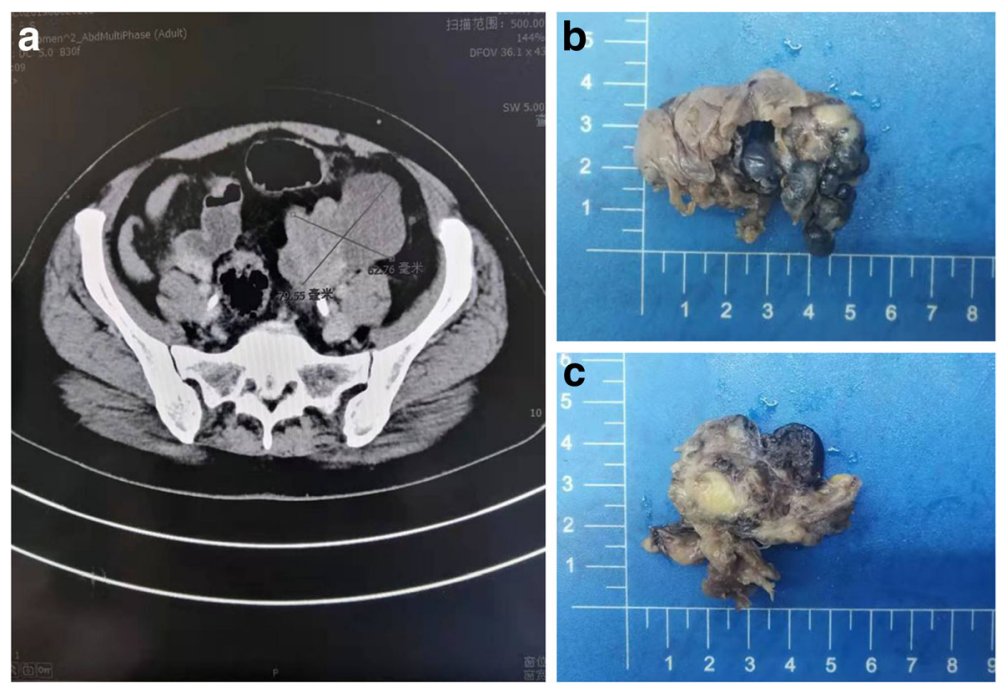

Fig. 1 CT findings and macroscopic observation for the tumor mass. a; CT scan revealed an irregular soft tissue density mass shadow in the left appendix area, with a size of $7.9 \times 6.2 \mathrm{~cm}$. The mass was nodular and lobulated with clear edges. The unevenness of the lesion was significantly enhanced after enhanced scanning. b: Grossly, the left ovary was enlarged and sized $5.5 \times 4.5 \times 4 \mathrm{~cm}$ with nodular appearance and gray-white to atropurpureus surface. c: Some areas of the cut surface were solid and gray-white with intermediate texture, and some areas were spongy and atropurpureus with soft texture

such as teratoma, mucinous cystadenocarcinoma, and dermoid cysts [12]. There were only 31 cases of primary ovarian angiosarcomas in the previous literatures $[10$, 12-34] . In this article, we reported one case with primary ovarian angiosarcomas, and then a comprehensive literature review was carried out to investigate the clinical features and prognosis of the tumor (Table 2). Primary angiosarcoma of ovary mainly occurred in premenopausal women with an averaged age of 33 years old. Only 3 cases occurred in postmenopausal women with the oldest one aged 81 years old [12, 25, 31]. In pediatric patients, the ovarian angiosarcoma was reported with the youngest age of 11 years old [27, 32-34]. Most patients had abdominal pain and distension, while the cases were accompanied by ascites or hemoperitoneum [25]. In most cases, the tumors were unilateral with the majority at the right ovary and 3 cases were bilateral $[20,27,30]$. The range of the size of the tumors was in a range of $2.1-30 \mathrm{~cm}$.

Histopathological confirmation is essential for the final diagnosis of primary ovarian angiosarcoma. Generally, the histological characteristics of ovarian angiosarcoma

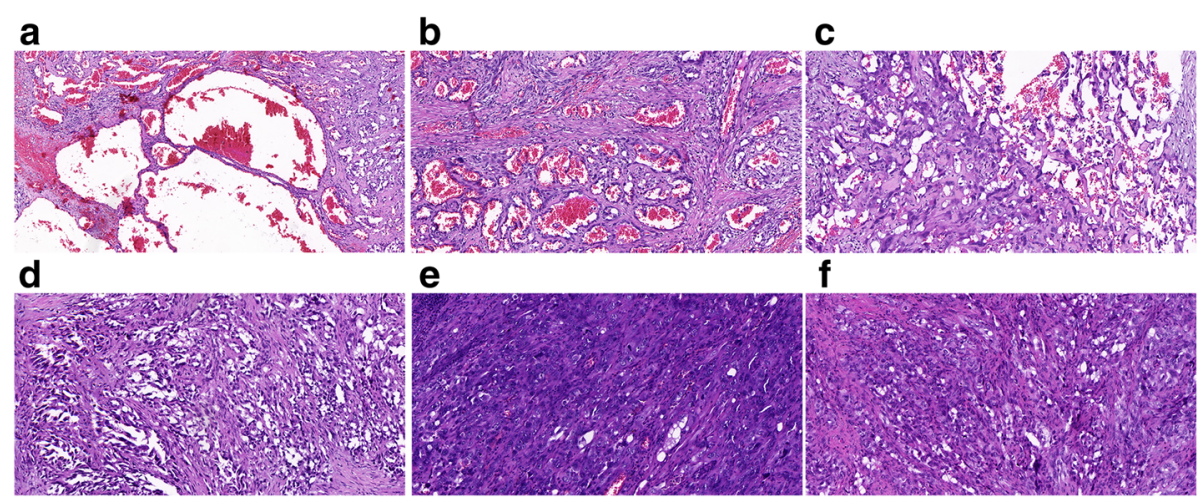

Fig. 2 Pathological findings of the tumor. a: In well-differentiated areas, there were many vascular lumens of different sizes, dilated partly and filled with blood (4X); $\mathbf{b}$ : The lumens were lined with flattened or obese mildly atypical endothelial cells (10X); $\mathbf{c}$ and $\mathbf{d}$ : Some areas tumor cells were lined in an irregular labyrinth cavity structure, with the lumen expanding and anastomosing with each other. It was covered with one or more layers of swollen endothelial cells, showing papillary and boot-nail protruding into the lumen (10x). e: In the poorly differentiated areas, fusiform and epithelioid tumor cells formed solid nests without obvious channel and some tumor cells, which showed significant pleomorphism with vacuolated nuclei and obvious nucleoli scattered in patch. Mitotic were 5 to 10 per 10 high power field and included pathological karyokinesis (10x). f: Vacuoles cells that similar to adipoblast cells were observed in focal lesions (10x) 


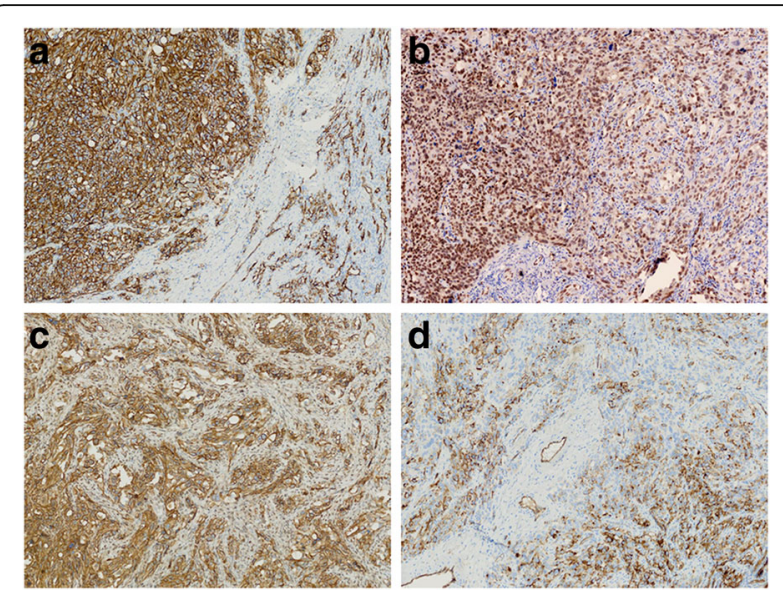

Fig. 3 The tumor cells were positive for CD31 (a), ERG (B), D2-40 (c) in a strong and diffused manner. CD34 stain showed focal positivity (d) under a magnification of $20 \times$

were complex and diverse. Irregular vascular lumen structures could be seen in tumor tissues as the lumens confluent and communicated mutually. The cavity was covered with atypical cells [19]. Part of tumor cells was bosselated. In some cases, tumor cells showed solid flaky distribution, which showed cytologic atypia morphology with plump cytoplasm, eosinophilic feature, large nucleus, deep nuclear chromatin, as well as significant nucleoli and common mitotic figures. In addition, singe cells can perform as a vessel in some regions [35]. In our case, there was a mixture structure with well differentiated vascular area. The areas of the vascular cavity communicated with each other and lined with spike-like heterotypic cells, as well as distribution of the solid flake spindle cells and epithelioid cells area. The variety of tissue structure and cell morphology reflected the complicacy and multiformity of morphology of angiosarcoma, which caused difficulties in clinical diagnosis.

CD31 is expressed in more than 90\% of angiosarcomas, and the positive rate of CD34 in angiosarcomas is $50-60 \%$ [36]. In poorly differentiated angiosarcomas, the sensitivity and specificity of CD31 were more effective than that of CD34. In recent years, the new antibody (e.g. ERG and Fli1) mainly expressed in the vascular endothelium can be used to mark benign and malignant tumors of vascular origin with high specificity. Nevertheless, it could also be expressed in some tumors of nonvascular origin [37, 38]. Therefore, the combination of CD31, CD34, ERG, Fli1 and other antibodies was more conducive to accurate diagnosis. In this case, the tumor cells were positive for CD31 and CD34 stain with focal positivity. D2-40 can be expressed in some patients with angiosarcomas [39]. Our results showed that D2-40 was diffuse and strongly positive, which further validated the vascular origin of the tumor.
Highly differentiated angiosarcoma should be differentiated from benign hemangioma, especially anastomosing hemangiomas. Grossly, ovarian hemangioma usually located in the ovarian medulla with polycystic, spongy and bleeding areas. The clear boundary between tumor and surrounding tissue was an important indicator for the distinguishing the hemangioma and highly differentiated angiosarcoma. The vascular cavities of anastomosing hemangiomas showed anastomosis with each other and lined with flattened or hobnail-like endothelial cells. There was no atypia among these cells, while highly differentiated angiosarcoma cells showed cytological atypia and invasion of surrounding tissues [40]. In addition, juvenile cellular hemangioma was an important differential diagnosis. In a previous study, Prus reported a case of infantile hemangioma in the ovary of a neonate [41]. The tumor was composed of blood vessels of different sizes lined with swollen endothelial cells, together with eosinophilic cytoplasm and vacuolated nuclei. Small nucleoli and karyokinesis were seen. No pathological karyokinesis were observed.

Poorly differentiated angiosarcomas are often composed of spindle cells and epithelioid cells with significant atypia, which is easily confused with sarcomatoid cancer and soft tissue sarcomas. Sarcomatoid carcinomas usually present well-differentiated carcinomatous components expressing epithelial immune markers (e.g. ck, ck7, and ck8/18). Meanwhile, vascular markers (e.g. CD31) were negative, which could distinguish them from angiosarcomas. For the other soft tissue sarcomas such as leiomyosarcoma, the tumor cells were usually arranged in beam of the spindle cells, with flake of epithelioid cells focally. The present of structure of vascular compartment suggested the diagnosis of angiosarcoma. A panel of immunohistochemical antibodies including SMA, Desmin, CD31 and ERG were conducive to the identification of these tumors.

Tumor cells of high-grade ovarian serous carcinoma and clear cell carcinoma are often arranged like adenoids or glandular cysts, which protruded into the glandular cavity with eosinophilic cytoplasm. There was obviously allotypic and hyperchromatic nuclei, as well as more mitosis. Moreover, tumor cells in some regions were arranged in a solid pattern. However, well-differentiated hemangio-like areas were accompanied by significant bleeding, irregular intersecting tubular-cystic structures. Immunohistochemically, these cells were negative for CK and CK7 and positive for CD31 and CD34, which contributed to the confirmation of the diagnosis. The yolk sac tumor presented multicystic, adenoid and cranny structures, and there were nail-like cells in the capsular space and adenoid cavity that were easily confused with the angiosarcoma. However, in the yolk sac tumor, there were Schiller-Duval body and the porous 
Table 2 Summary of outcomes and findings of cases with primary pure angiosarcomas of the ovary reported

\begin{tabular}{|c|c|c|c|c|c|c|c|}
\hline Literature & Case ID & Age, yr & Size, cm & Stage & Position & Follow up & $\begin{array}{l}\text { Postoperative adjuvant } \\
\text { therapy }\end{array}$ \\
\hline Patel et al., 1991 [13] & 1 & 42 & Not available & IV & Right & DOD, 18 days & None \\
\hline Cunningham et al., 1994 [14] & 2 & 19 & $12 \times 10$ & IV & Left & DOD, 7 mo & $\begin{array}{l}\text { Doxo/ifos, } 4 \text { cycles; cisplat- } \\
\text { num/etoposide, } 1 \text { cycle }\end{array}$ \\
\hline Nara et al., 1996 [15] & 3 & 33 & 4 & IV & Right & $\mathrm{DOD}, 2 \mathrm{mo}$ & None \\
\hline \multirow[t]{5}{*}{ Nielsen et al., 1997 [16] } & 4 & & & 1 & & NED & None \\
\hline & 5 & & & 1 & & $5.5 \mathrm{yr}-9 \mathrm{yr}$ & \\
\hline & 6 & & & 1 & & & \\
\hline & 7 & $20-32$ & $6-13$ & । & Not available & & \\
\hline & 8 & & & III & & $\mathrm{DOD}, 2 \mathrm{mo}$ & \\
\hline $\begin{array}{l}\text { Furihata et } \\
\text { al, } 1998[17]\end{array}$ & 9 & 46 & $21 \times 16 \times 13$ & $\begin{array}{l}\text { Not } \\
\text { available }\end{array}$ & Right & DOD, 9 mo & Cisplatin, 1 cycle; radiation \\
\hline $\begin{array}{l}\text { Lifschnitz-Mercer et } \\
\text { al, } 1998 \text { [9] }\end{array}$ & 10 & 25 & $13 \times 11 \times 5$ & III & Left & $\begin{array}{l}\text { Recurrent } \\
\text { disease, } 18 \text { mo+ }\end{array}$ & Doxo/ffos, 3 cycles \\
\hline \multirow{6}{*}{$\begin{array}{l}\text { Nucci et } \\
\text { al, } 1998[18]\end{array}$} & 11 & 35 & & IV & Not available & DOD "quickly" & None \\
\hline & & & & I & Left & & \\
\hline & 12 & 25 & $3.5-14$ & III & Not available & NED, 3 mo & \\
\hline & 13 & 42 & & & & $\mathrm{DOD}, 2 \mathrm{yr}$ & \\
\hline & & & & 1 & Right & & \\
\hline & 14 & 27 & & & & NED, 14 mo & \\
\hline Platt et al., 1999 [19] & 15 & 40 & $11 \times 8$ & IV & Left & $\mathrm{NED}, 2 \mathrm{mo}$ & MAID, 4 cycles \\
\hline Twu et al., 1999 [20] & 16 & 40 & Not available & IV & Bilateral & $\mathrm{DOD}, 7 \mathrm{mo}$ & Doxo/ifos, 8 cycles \\
\hline Davidson et al., 2005 [21] & 17 & 19 & $18 \times 15 \times 15$ & III & Left & DOD, 1 yr & Doxo/ifos, 6 cycles \\
\hline QuesenbErr et al., 2005 [22] & 18 & 31 & $\begin{array}{l}19 \times 16 \\
\times 8.5\end{array}$ & IC & Left & NED, 1 yr & MAID, 3 cycles \\
\hline Jha et al., 2005 [23] & 19 & 28 & $20 \times 25$ & 1 & Right & NED, 10 mo & Doxo/ifos, 6 cycles \\
\hline Vavilis et al., 2007 [24] & 20 & 29 & $8 \times 6$ & Not available & Right & Not available & None \\
\hline Bradford et al., 2010 [25] & 21 & 67 & $12 \times 6 \times 8$ & IIIC & Right & $\mathrm{DOD}, 1 \mathrm{mo}$ & Paclitaxel, 1 cycle \\
\hline Serrano et al., 2010 [26] & 22 & 23 & 14 & IIIC & Left & NED,12 mo & Epirubicin/ifos, 6 cycles \\
\hline Iljazovic et al., 2011 [27] & 23 & 11 & $\begin{array}{l}\text { Left: } 17 \times 14 \times 6 \\
\text { Right: } 14 \times 7 \times 5\end{array}$ & $\| A$ & Bilateral & NED, $10 \mathrm{mo}$ & Chemotherapy, 6 cycles \\
\hline Bosmuller et al., 2011 [11] & 24 & 81 & $\begin{array}{l}30 \times 18 \\
\times 12\end{array}$ & 1 & Right & NED, 5 mo & Doxo, 4 cycles \\
\hline Guseh et al., 2012 [28] & 25 & 40 & $15 \times 11 \times 2$ & IIIC & Right & Recurrent disease, $18 \mathrm{mo}+$ & Doxo/ifos, 3 cycles \\
\hline Yaqoob et al., 2014 [29] & 26 & 41 & $7 \times 6 \times 2$ & IA & Left & Not available & None \\
\hline Wu et al., 2014 [30] & 27 & 45 & $\begin{array}{l}\text { Left: } 7.1 \times 4.7 \\
\text { Right: } 2.1 \times 1.4\end{array}$ & IIIA & Bilateral & DOD, $30 \mathrm{mo}$ & MAID, 6 cycles \\
\hline Gaiolla et al., 2014 [31] & 28 & 71 & 4.4 & Not available & Right & $\mathrm{DOD}, 27 \mathrm{mo}$ & $\begin{array}{l}\text { Gemcitabine/zoledronic } \\
\text { acid, } 2 \text { cycles }\end{array}$ \\
\hline Darre et al., 2017 [32] & 29 & 12 & $17 \times 14 \times 9$ & $\|$ & Right & NED "not afford it" & None \\
\hline Priyakumari et al., 2018 [33] & 30 & 11 & $15 \times 10 \times 8$ & Not available & Right & NED "unwilling for treatment" & None \\
\hline Pariury et al., 2019 [34] & 31 & 11 & Not available & Not available & Right & NED, 43 mo & Demcitabine/doxo, 12 cycles \\
\hline Current case & 32 & 47 & $7 \times 4 \times 4$ & 1 & Left & NED, 8 mo+ & Olaparib, anti-PD-1 \\
\hline
\end{tabular}

NED No evidence of disease; DOD Dead of disease; yr Year; mo Month. MAID Mesna + doxorubicin + ifosfamide + dacarbazine

edema. The immunohistochemisty results for SALL4, AFP and Glypican-3 were positive (Table 3). The angiosarcoma may originate from the teratoma. Therefore, extensive sampling was required to investigate the benign teratoma components.
It is necessary to exclude metastatic hemangiosarcoma before the diagnosis of primary ovarian sarcoma of the ovary. In our case, the patient underwent a comprehensive physical examination. No tumor was found in other parts of the body and there was no history of 
Table 3 Immunohistochemisty of angiosarcoma and differential diagnosis

\begin{tabular}{|c|c|c|c|c|}
\hline Immunohistochemisty & Angiosarcoma & Serous carcinoma & Clear cell carcinoma & Yolk sac tumor \\
\hline CK & $+/-$ & + & + & $+/-$ \\
\hline CK7 & - & + & + & - \\
\hline SALL4 & - & - & - & + \\
\hline CD34,CD31, ERG & + & - & - & - \\
\hline WT-1 & - & + & - & - \\
\hline P53 & - & + & - & - \\
\hline Napsin $A$ & - & - & + & - \\
\hline HNF-1 $\beta$ & - & - & + & - \\
\hline AFP & - & - & - & + \\
\hline Glypican-3 & - & - & - & + \\
\hline D2-40 & + & - & - & - \\
\hline
\end{tabular}

angiosarcoma. Therefore, the neoplasm in ovary was considered as primary angiosarcoma.

Cytogenetically, the expression of FLT1 and AKT3 in the angiosarcomas patients was up-regulated. Recent studies demonstrated that the PTPRB and PLCG1 genes involved in angiogenesis were mutated in angiosarcomas. In addition, $9 \%$ of cases showed aberrant $C I C$ and $7 \%$ of the cases showed KDR mutation. MYC gene amplification was confirmed to play key roles in secondary angiosarcomas. Further studies are required to investigate the genetic mutations of most primary angiosarcomas [42].

To date, the major treatment options for angiosarcoma include surgical debulking and post-operative adjuvant chemotherapy and radiotherapy. In a previous study, surgical resection was performed in the majority of cases, while some patients underwent adjuvant chemotherapy after surgery. Common chemotherapy regimens for primary ovarian angiosarcoma include the MAID regimen, as well as ifosfamide and doxorubicin, as well as gemcitabine and cisplatin [28]. Jha et al. reported a 28-year-old woman received adjuvant chemotherapy with ifosfamide + doxorubicin for fertility preservation, which finally delivered a healthy living baby [23]. Currently, clinical staging is considered as the most important factor affecting the prognosis of patients. In the previous study, stages were obtained for 27 patients in the literature $[9,11,13-16,18-23,25-32]$, including 11 patients with stage I, 2 patients with stage II and 14 patients with stage III and IV. Finally, follow-up information of 10 cases (stage I: 8 cases; stage II: 2 cases) was obtained. All the patients were followed up for 3 months to 9 years, and were confirmed with disease-free survival. For the 14 cases at stage III, 9 cases were died about 18 days or 30 months after diagnosis (Table 2).

In this case, the patient underwent 15 fractions of radiation and adjuvant targeted therapy with the PARP inhibitor (i.e. Olaparib). In addition, PD-L1 determination was performed in the tumor samples, which indicated PD-L1 positivity. Anti-PD-1 immunotherapy was also given to her. No evidence of disease recurrence was noticed in the 9-month follow-up. In recent years, PARP inhibitors have been approved and applied in the treatment of epithelial ovarian cancer, with satisfactory efficiency [43]. In a multi-centered phase I study, the combination of trabectedin and olaparib showed promising efficiency for treating soft tissue sarcoma [44]. In future, further studies are required to investigate the roles and efficiency of PARP inhibitors in treating ovarian angiosarcoma. The effects of anti-PD-1 in the treatment of angiosarcoma are still lacking of large experimental studies. Sindhu [45] et al. reported a case of nasal angiosarcoma showing satisfactory efficiency after anti-PD-1 therapy. This indicated that the anti-PD-1 immunotherapy may serve as a promising treatment option for treating angiosarcoma.

However, after taking the efficiency of such agent in treating other tumors into considering, its application in treating angiosarcoma is still promising [42].

\section{Conclusion}

Ovarian angiosarcoma is very rare with no specific clinical symptoms. The prognosis of patients with advanced stage is still poor. The diagnosis of poorly differentiated angiosarcoma is highly relied on the identification of communicating and typical vascular-like structures. Immunopositivity for a specific endothelial marker (e.g. CD31, CD34, EGR, or Fli1) is a diagnostic prerequisite. Complete surgical resection and postoperative adjuvant chemoradiotherapy are routine treatment methods. In future, targeted therapy may be a new type of exploratory therapy.

\section{Acknowledgements}

Not applicable.

Authors' contributions

$\mathrm{YH}$ drafted the article or revised it critically for important intellectual content: LM, LRT, QSM made contributions to the conception and design of the 
study $_{i,} \mathrm{HG}, \mathrm{CHZ}$ made contributions to the acquisition of data, or analysis and interpretation of data; LXM finally approved the version to be submitted.

\section{Funding}

Not available.

\section{Availability of data and materials}

All the data were available upon appropriate request

\section{Ethics approval and consent to participate}

The study protocols were approved by the Ethical Committee of Tai'an Central Hospital.

\section{Consent for publication}

All the authors agree to submit to your journal.

\section{Competing interests}

None.

Received: 13 August 2020 Accepted: 20 January 2021

Published online: 28 January 2021

\section{References}

1. Young RJ, Brown NJ, Reed MW, Hughes D, Woll PJ. Angiosarcoma. Lancet Oncol. 2010;11:983-91.

2. Mullin C, Clifford CA. Histiocytic sarcoma and Hemangiosarcoma update. Vet Clin North Am Small Anim Pract. 2019;49:855-79.

3. Hur CJ, Min BR, Lee YJ, Jang BK, Hwang JS, Kim ES, et al. Clinical courses of primary hepatic angiosarcoma: retrospective analysis of eight cases. Korean J Gastroenterol. 2015;65:229-35.

4. Falk S, Krishnan J, Meis JM. Primary angiosarcoma of the spleen. A clinicopathologic study of 40 cases. Am J Surg Pathol. 1993;17:959-70.

5. Galmiche L, Morel HP, Moreau A, Labrosse PA, Coindre JM, Heymann MF. Primary adrenal angiosarcoma. Ann Pathol. 2004;24:371-3.

6. Ramlawi B, Leja MJ, Abu Saleh WK, Al Jabbari O, Benjamin R, Ravi V, et al. Surgical treatment of primary cardiac sarcomas: review of a singleinstitution experience. Ann Thorac Surg. 2016:101:698-702.

7. Grewal JS, Daniel AR, Carson EJ, Catanzaro AT, Shehab TM, Tworek JA. Rapidly progressive metastatic multicentric epithelioid angiosarcoma of the small bowel: a case report and a review of literature. Int J Color Dis. 2008;23:745-56.

8. Kruse AJ, Sep S, Slangen BF, Vandevijver NM, Van Gorp T, Kruitwagen $\mathrm{RF}$, et al. Angiosarcomas of primary gynecologic origin: a clinicopathologic review and quantitative analysis of survival. Int J Gynecol Cancer. 2014;24:4-12.

9. Khan JA, Maki RG, Ravi V. Pathologic angiogenesis of malignant vascular sarcomas: implications for treatment. J Clin Oncol. 2018;36:194-201.

10. Lifschitz-Mercer B, Leider-Trejo L, Messer G, Peyser MR, Czernobilsky B. Primary angiosarcoma of the ovary: a clinicopathologic, immunohistochemical and electronmicroscopic study. Pathol Res Pract. 1998;194:183-7.

11. Young RH, Scully RE. Sarcomas metastatic to the ovary: a report of 21 cases. Int J Gynecol Pathol. 1990;9:231-52.

12. Bösmüller H, Gruber C, Haitchi-Petnehazy S, Wagner D, Webersinke G, Hauptmann S. Primary angiosarcoma of the ovary with prominent fibrosis of the ovarian stroma. Case report of an 81-year old patient. Diagn Pathol. 2011;6:65

13. Patel T, Ohri SK, Sundaresan M, Jackson J, Desa LA, Davey AT, et al. Metastatic angiosarcoma of the ovary. Eur J Surg Oncol. 1991;17:295-9.

14. Cunningham MJ, Brooks JS, Noumoff JS. Treatment of primary ovarian angiosarcoma with ifosfamide and doxorubicin. Gynecol Oncol. 1994;53: 265-8.

15. Nara M, Sasaki T, Shimura S, Yamamoto M, Oshiro T, Kaiwa Y, et al. Diffuse alveolar hemorrhage caused by lung metastasis of ovarian angiosarcoma. Intern Med. 1996:35:653-6.

16. Nielsen GP, Young RH, Prat J, Scully RE. Primary angiosarcoma of the ovary: a report of seven cases and review of the literature. Int J Gynecol Pathol. 1997;16:378-82.

17. Furihata M, Takeuchi T, Iwata J, Sonobe H, Ohtsuki Y, Wakatsuki A, et al. Primary ovarian angiosarcoma: a case report and literature review. Pathol Int. 1998;48:967-73.
18. Nucci MR, Krausz T, Lifschitz-Mercer B, Chan JK, Fletcher CD Angiosarcoma of the ovary: clinicopathologic and immunohistochemical analysis of four cases with a broad morphologic spectrum. Am J Surg Pathol. 1998;22:620-30.

19. Platt JS, Rogers SJ, Flynn EA, Taylor RR. Primary angiosarcoma of the ovary: a case report and review of the literature. Gynecol Oncol. 1999;73:443-6.

20. Twu NF, Juang CM, Yeng MS, Lu CJ, Lai CZ, Chao KC. Treatment of primary pure angiosarcoma of ovary with multiple lung metastases: a case report. Eur J Gynaecol Oncol. 1999;20:383-5.

21. Davidson B, Abeler VM. Primary ovarian angiosarcoma presenting as malignant cells in ascites: case report and review of the literature. Diagn Cytopathol. 2005;32:307-9.

22. Quesenberry CD, Li C, Chen AH, Zweizig SL, Ball HG 3rd. Primary angiosarcoma of the ovary: a case report of stage I disease. Gynecol Oncol. 2005;99:218-21.

23. Jha S, Chan KK, Poole CJ, Rollason TP. Pregnancy following recurrent angiosarcoma of the ovary--a case report and review of literature. Gynecol Oncol. 2005;97:935-7.

24. Vavilis D, Papadopoulos N, Agorastos T, Efstratiou I, Kommoss F, Bontis IN. Primary ovarian angiosarcoma--review of the literature and report of a case with coexisting chylothorax. Eur J Gynaecol Oncol. 2007;28:287-9.

25. Bradford L, Swartz K, Rose S. Primary angiosarcoma of the ovary complicated by hemoperitoneum: a case report and review of the literature. Arch Gynecol Obstet. 2010;281:145-50.

26. Serrano C, García Á, Brana I, Pérez-Benavente A, Oaknin A. Angiosarcoma of the ovary: is it always a lethal disease? J Clin Oncol. 2010;28:e675-7.

27. Iljazović E, Tomić S, Mustedanagić-Mujanović J, Karasalihović Z, Kuljanin M, Fatušić Z, et al. Angiosarcoma of the ovary in an 11 year old girl: case report and review of the literature. Bosn J Basic Med Sci. 2011;11:132-6.

28. Guseh SH, Bradford LS, Hariri LP, Schorge JO. Ovarian angiosarcoma: extended survival following optimal cytoreductive surgery and adjuvant chemotherapy. Gynecol Oncol Case Rep. 2012:4:23-5.

29. Yaqoob N, Nemenqani D, Khoja H, Hafez M, Tulbah A, Al-Dayel F. Ovarian angiosarcoma: a case report and review of the literature. J Med Case Rep. 2014;8:47.

30. Wu PC, Yue CT, Huang SC. Complete response after MAID treatment for advanced primary ovarian angiosarcoma: case report and literature review. Eur J Gynaecol Oncol. 2014;35:318-21.

31. Gaiolla RD, Duarte IX, Bacchi CE, Paiva CE. A metastatic ovarian angiosarcoma mimicking hematologic neoplasia at diagnosis. Case Rep Oncol. 2014;7:260-5.

32. Darré T, Aboubakari AS, N'Bortche BK, Bassowa A, Adani-Ifé S, Napo-Koura G. Primary ovarian angiosarcoma in a 12-year -old girl: a case report of an exceptional localization in a context of limited resources country. BMC Clin Pathol. 2017:17:16

33. Thankamony P, Chandar R, Kattoor J, Nair RK. Pediatric primary ovarian Angiosarcoma: from rarity to a realization. J Pediatr Adolesc Gynecol. 2018; 31:629-31.

34. Pariury $\mathrm{H}$, Golden C, Huh WW. Pediatric ovarian angiosarcoma treated with systemic chemotherapy and cytoreductive surgery with heated intraperitoneal chemotherapy: Case report and review of therapy. Pediatr Blood Cancer. 2019;66:e27753.

35. Irving JA, McCluggage WG. Ovarian spindle cell lesions: a review with emphasis on recent developments and differential diagnosis. Adv Anat Pathol. 2007:14:305-19.

36. Miettinen $M$, Lindenmayer AE, Chaubal A. Endothelial cell markers CD31, $\mathrm{CD} 34$, and $\mathrm{BNH} 9$ antibody to $\mathrm{H}$ - and $\mathrm{Y}$-antigens--evaluation of their specificity and sensitivity in the diagnosis of vascular tumors and comparison with von Willebrand factor. Mod Patho. 1994;7:82-90.

37. Miettinen M, Wang ZF, Paetau A, Tan SH, Dobi A, Srivastava $S$, et al. ERG transcription factor as an immunohistochemical marker for vascular endothelial tumors and prostatic carcinoma. Am J Surg Pathol. 2011;35: 432-41.

38. Folpe AL, Chand EM, Goldblum JR, Weiss SW. Expression of Fli-1, a nuclear transcription factor, distinguishes vascular neoplasms from potential mimics. Am J Surg Pathol. 2001;25:1061-6.

39. Fukunaga M. Expression of D2-40 in lymphatic endothelium of normal tissues and in vascular tumours. Histopathology. 2005:46:396-402.

40. Gunduz M, Hurdogan O. Cystic anastomosing hemangioma of the ovary: a case report with immunohistochemical and ultrastructural analysis. Int J Surg Pathol. 2019;27:437-40. 
41. Prus D, Rosenberg AE, Blumenfeld A, Udassin R, Ne'eman Z, Young RH, et al. Infantile hemangioendothelioma of the ovary: a monodermal teratoma or a neoplasm of ovarian somatic cells? Am J Surg Pathol. 1997;21:1231-5.

42. Cao J, Wang J, He C, Fang M. Angiosarcoma: a review of diagnosis and current treatment. Am J Cancer Res. 2019;9:2303-13.

43. Ashworth A, Lord CJ. Synthetic lethal therapies for cancer: what's next after PARP inhibitors? Nat Rev Clin Oncol. 2018;15:564-76.

44. Grignani G, D'Ambrosio L, Pignochino Y, Palmerini E, Zucchetti M, Boccone $P$, et al. Trabectedin and olaparib in patients with advanced and nonresectable bone and soft-tissue sarcomas (TOMAS): an open-label, phase 1b study from the Italian sarcoma group. Lancet Oncol. 2018;19:1360-71.

45. Sindhu S, Gimber LH, Cranmer L, McBride A, Kraft AS. Angiosarcoma treated successfully with anti-PD-1 therapy - a case report. J Immunother Cancer. 2017;5:58.

\section{Publisher's Note}

Springer Nature remains neutral with regard to jurisdictional claims in published maps and institutional affiliations.

Ready to submit your research? Choose BMC and benefit from:

- fast, convenient online submission

- thorough peer review by experienced researchers in your field

- rapid publication on acceptance

- support for research data, including large and complex data types

- gold Open Access which fosters wider collaboration and increased citations

- maximum visibility for your research: over $100 \mathrm{M}$ website views per year

At $\mathrm{BMC}$, research is always in progress.

Learn more biomedcentral.com/submissions 